\author{
Krzysztof Kołodziejczyk \\ https://orcid.org/0000-0002-3262-311X \\ Uniwersytet Wrocławski \\ Wydział Nauk o Ziemi i Kształtowania Środowiska \\ Zakład Geografii Regionalnej i Turystyki \\ krzysztof.kolodziejczyk@uwr.edu.pl
}

\title{
ZABYTKOWA LINIA TRAMWAJOWA WE WROCŁAWIU - ANALIZA OFERTY TURYSTYCZNEJ Z PUNKTU WIDZENIA TURYSTYKI MIEJSKIEJ
}

\begin{abstract}
Abstrakt: Celem autora artykułu jest ocena funkcjonowania turystycznej linii tramwajowej we Wrocławiu w 2018 r. pod względem atrakcyjności oferty dla turystów, zainteresowania przejazdami oraz kosztów i opłacalności jej utrzymania, by ostatecznie wskazać pewne ogólne wnioski dotyczące obecności tego typu oferty w turystyce miejskiej. Zakres czasowy, uwzględniony w analizie w niniejszej pracy, jest szczególnie ważny, ponieważ rozszerzenie liczby przewoźników z jednego do dwóch pozwoliło na wprowadzenie wielu zmian w ofercie. Na podstawie danych ze sprzedaży biletów można stwierdzić, że linia cieszy się największą popularnością w lipcu i sierpniu, choć nawet wtedy średni odsetek zajętych miejsc siedzących jest niższy niż $50 \%$. Kursy z przewodnikiem są nieco mnie popularne niż przejazdy bez niego. W związku z tym w pracy przedstawiono pewne propozycje, które mogą przyczynić się do zwiększenia zainteresowania linią, takie jak wydłużenie czasu kursowania (w ciągu dnia i w skali roku) czy wprowadzenie nowych rodzajów biletów lub dodatkowych atrakcji.
\end{abstract}

Słowa kluczowe: zabytki techniki, zabytkowe tramwaje, transport, tramwajowe linie turystyczne, Wrocław.

\section{WSTĘP}

W większości miast o wykształconej funkcji turystycznej istnieje oferta specjalnych linii transportu zbiorowego (Mehring, 2017), których przeznaczeniem jest dowiezienie turystów do ważniejszych punktów zainteresowania (walorów krajoznawczych) lub pokazanie im głównych atrakcji w możliwie krótkim czasie. W niektórych przypadkach linie te mogą stać się same w sobie atrakcją turystyczną, funkcjonującą $\mathrm{w}$ formie samodzielnego produktu turystycznego (por. Kaczmarek, Stasiak, Włodarczyk, 2010; Meyer, 2015). Na takich liniach kursują najczęściej współczesne, specjalnie przystosowane pojazdy (np. piętrowe autobusy z odkrytym górnym pokładem $\mathrm{w}$ Wielkiej Brytanii, ale też $\mathrm{w}$ wielu innych miastach europejskich, np. w Berlinie), lecz w niektórych miastach - posiadających zabytkowe pojazdy komunikacji miejskiej - wykorzystuje się do tego celu historyczne wozy, co dodatkowo czyni ofertę atrakcyjniejszą. Ze względu na swój szczególny charakter druga opcja jest ceniona przez turystów, co najlepiej ilustrują przykłady Lizbony i Porto w Portugalii czy San Francisco w USA.

W Polsce w większości miast, w których funkcjonuje komunikacja tramwajowa, utrzymywane są linie turystyczne obsługiwane historycznymi wagonami (por. Kołodziejczyk, 2018). Taka oferta jest dostępna w Bydgoszczy, Częstochowie, Elblągu, Gdańsku, Krakowie, Łodzi, Poznaniu, Szczecinie, Warszawie i Wrocławiu. Linie te różnią się od siebie okresem funkcjonowania (przeważnie weekendy, na ogół w półroczu letnim lub w wakacje), długością, częstotliwością, wiekiem wykorzystywanego taboru, więc ich porównywanie jest dość trudne. W niniejszym artykule poddano analizie Zabytkową Linię Tramwajową kursującą we Wrocławiu. Jest ona o tyle ciekawa, że - w przeciwieństwie do linii $\mathrm{w}$ innych miastach - jej operatorem są stowarzyszenia, a nie miejski przewoźnik obsługujący inne, regularne linie. Ponadto funkcjonowanie linii jest finansowane przez Gminę Wrocław na zasadzie konkursu na realizację zadania publicznego przez organizacje pozarządowe. Taka sytuacja rodzi pewne trudności natury technicznej i administracyjnej, ale $z$ drugiej strony daje większą swobodę w kształtowaniu oferty, a jednocześnie pozwala na szerokie zaangażowanie miłośników historii techniki i starych tramwajów (czy autobusów). Warto tu podkreślić, że stolica Dolnego Śląska może się poszczycić najliczniejszą w kraju kolekcją zabytkowych 
pojazdów komunikacji miejskiej (Kołodziejczyk, 2012, 2018; Sielicki, 2013). Odzwierciedla ona zmiany zachodzące we wrocławskim transporcie zbiorowym od tramwajów konnych uruchomionych w 1877 r. (Sielicki, 2017), przez wprowadzenie napędu elektrycznego w 1893 r., po zachodzące od połowy XX w. przekształcenia mające na celu dostosowanie transportu publicznego do coraz intensywniejszego ruchu kołowego i wzrastającej liczby mieszkańców (Bufe, 1992; Lewandowski, Molecki, 2006; Maciejewski, 2004; Sielicki, 2012a, 2012b; Wojcieszak, 1993). Niestety stan poszczególnych pojazdów w tej kolekcji jest bardzo zróżnicowany - od sprawnych po nienadające się do użytku (Sielicki, 2013).

Oferta linii turystycznych obsługiwanych zabytkowym taborem $z$ jednej strony wpisuje się w turystykę miejską, z drugiej zaś - w turystykę dziedzictwa (przy czym te pojęcia w żadnym wypadku nie są rozłączne). Za turystykę miejską można uznawać w najprostszym rozumieniu wszystkie jej formy w miastach (Marak, Wyrzykowski, 2010; Matczak, 1989), ale jednocześnie „formy turystyki związane z walorami i zagospodarowaniem turystycznym występującymi na obszarach miejskich” oraz „turystykę, której celem jest odwiedzanie i poznawanie miasta traktowanego jako dziedzictwo kulturowe i uznawanego za niepodzielny element przestrzeni turystycznej" (Kowalczyk, 2005, s. 157; por. Ashworth, 1992; Mika, 2007a; Page, 1995; Sala, 2012). Tramwaje czy transport publiczny przynajmniej od XIX w. są immanentnym elementem funkcjonowania krajobrazu miejskiego, stąd rola dziedzictwa $\mathrm{z}$ nimi związanego może stanowić jeden $\mathrm{z}$ ważniejszych przedmiotów zainteresowania turysty miejskiego (jednocześnie taki turysta przemieszcza się tymi środkami transportu, doświadczając miasta). Zabytkowe środki komunikacji zbiorowej umożliwiają dostrzeżenie zmian zachodzących w sposobach podróżowania i rozwoju techniki, wpisując się w turystykę dziedzictwa kulturowego, rozumianą jako podróże w celu poznawania miejsc, przedmiotów kultury materialnej i duchowej, a także działań, które w sposób autentyczny przedstawiają historię oraz wartości kulturowe dawne i teraźniejsze (Lipińska, 2011). W tego rodzaju turystyce niezwykle istotną rolę odgrywa bliski kontakt jej uczestników z obiektami zabytkowymi (Mikos von Rohrscheidt, 2008), co w przypadku linii turystycznej, obsługiwanej historycznym taborem, realizowane jest chyba w najpełniejszym wymiarze. Analizowaną ofertę można też wiązać z turystyką motoryzacyjną, rozumianą - w przeciwieństwie do turystyki samochodowej, definiowanej głównie przez środek transportu (Marak, Wyrzykowski, 2010; Mika, 2007b) - jako podróże, których celem jest odwiedzanie miejsc związanych z motoryzacją, ważnych dla jej rozwoju (np. muzea motoryzacji, fabryki samochodowe, eventy o tej tematyce). Ten rodzaj turystyki nie doczekał się jeszcze zbyt wielu opracowań naukowych (Cudny, 2018; Cudny, Horňák, 2016), ale pojęcie to dość powszechnie funkcjonuje w środowisku miłośników transportu (czego wyrazem jest m.in. serwis Turystyka-motoryzacyjna.pl). Jak dotąd przeprowadzono nieliczne naukowe analizy dotyczące funkcjonowania linii turystycznych obsługiwanych zabytkowym taborem (por. Kołodziejczyk, 2011).

Celem autora artykułu jest ocena funkcjonowania turystycznej linii tramwajowej we Wrocławiu przez pryzmat jej oferty - atrakcyjności propozycji dla turystów, zainteresowania przejazdami (pośrednio frekwencji) oraz kosztów i opłacalności jej utrzymania. Autor tekstu przeprowadził analizę kameralną dostępnych materiałów promocyjnych związanych z linią i określił sposób jej funkcjonowania. Cennym źródłem informacji były dane o sprzedaży biletów z całego sezonu, częściowo przygotowane w podziale na rodzaje biletów i poszczególne kursy, które poddano analizie statystycznej, mającej na celu określenie m.in. frekwencji ogólnej i w poszczególnych okresach funkcjonowania linii. Uzyskano także dane finansowe dotyczące łącznych przychodów i wydatków, które pozwoliły odpowiedzieć na pytanie, czy taka linia byłaby w stanie utrzymać się bez dotacji gminy. Efektem uzyskanych informacji stała się analiza SWOT (Tylińska, 2005), która jest metodą dość często wykorzystywaną w naukach o turystyce, nie tylko w kontekście obszarów recepcji (Goranczewski, Puciato, 2010), ale również konkretnych atrakcji turystycnych (Kruczek 2011; Nowacki, 2000). W końcowej części pracy zawarto zalecenia w zakresie poprawy (rozwoju) dotychczasowej oferty.

\section{FUNKCJONOWANIE ZABYTKOWEJ LINII TRAMWAJOWEJ W 2018 R.}

Zabytkowa Linia Tramwajowa kursuje po Wrocławiu od 2009 r. i jest uruchamiana na zlecenie Urzędu Miejskiego Wrocławia (obecnie Biuro Promocji Miasta i Turystyki), ale dotychczas była obsługiwana wyłącznie przez Towarzystwo Miłośników Wrocławia (TMW). W 2018 r. po raz pierwszy operatorem stało się konsorcjum stowarzyszeń, do którego poza TMW wszedł Klub Sympatyków Transportu Miejskiego (KSTM). Pozwoliło to na większe zróżnicowanie taboru kursującego na linii, ponieważ łącznie do jej obsługi przewidziano cztery wagony (rys. 1): Linke-Hofmann Standard "Juliusz"1 z 1929 r. (TMW), Konstal 4N1 „Enusia” z 1960 r. (KSTM), Konstal 102N „Strachotek” z 1969 r. (TMW) oraz Konstal 102Na z 1972 r., kompleksowo wyremontowany w latach 2014-2018 (KSTM). Poza tramwajem Linke-Hofmann Standard wszystkie wagony posiadają nagłośnienie. Względem poprzedniego roku wprowadzono też pewne zmiany w zakresie prze- 


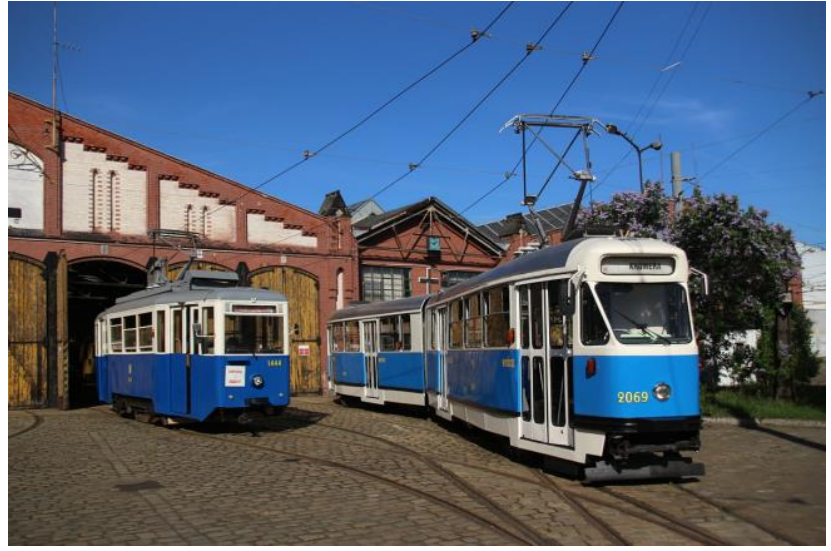

Rys. 1. Tramwaje kursujące na trasach A i B Zabytkowej Linii Tramwajowej: wagon Konstal 4N1 z 1960 r. i wagon przegubowy Konstal 102Na z 1972 r. Źródło: fot. K. Kołodziejczyk, 2018

biegu tras, cennika i sposobu organizacji przewozów, planując kilkanaście miejsc zatrzymania w pobliżu najważniejszych atrakcji turystycznych. Na początku funkcjonowania linii (od 2009 do około 2012 r.) istniały też przystanki pośrednie, ale później TMW z nich zrezygnowało.

Zabytkowa Linia Tramwajowa w 2018 r. kursowała od 16 czerwca do 9 września w soboty i niedziele w godz. 12.00-21.00 na czterech trasach (rys. 2), których punktem wspólnym był stylizowany przystanek na pl. Teatralnym, sąsiadujący z gmachem opery i odległy około 400 m od Rynku. Trasa A wiodła z opery do wpisanej na listę światowego dziedzictwa UNESCO Hali Stulecia oraz zoo, zaś trasa B - w przeciwną stronę, ale innymi ulicami, co pozwalało na zobaczenie po drodze różnych zabytków i atrakcji (m.in. Dzielnica Czterech Wyznań, Pałac Królewski, kościoły św. Krzysztofa i św. Wojciecha, Muzeum Narodowe, Ostrów Tumski, park Szczytnicki, Most Zwierzyniecki, kościół NMP na wyspie Piasek, Hala Targowa, Ossolineum, gmach główny Uniwersytetu Wrocławskiego, Arsenał). Cała podróż tam i z powrotem zajmowała nieco ponad 1,5 godziny z półgodzinnym postojem koło Hali Stulecia, pozwalającym na szybkie obejrzenie obiektu i jego otoczenia (była też oczywiście możliwość powrotu kolejnym, późniejszym kursem). Trasy C i D miały natomiast charakter okrężny $\mathrm{i}-\mathrm{w}$ przeciwieństwie do uprzednio wymienionych - nie było na nich przystanków pośrednich. Pierwsza z nich prowadziła przez Stare Miasto oraz poddawaną ostatnio rewitalizacji dzielnicę Nadodrze. Przejazd tą linią zajmował około 50 minut. Druga ze wspomnianych tras - przewidziana jako wieczorna - została utworzona w celu umożliwienia turystom zobaczenia w nieco ponad pół godziny najciekawiej podświetlonych zabytków (m.in. Dom Handlowy Renoma, Dworzec Główny, kościoły

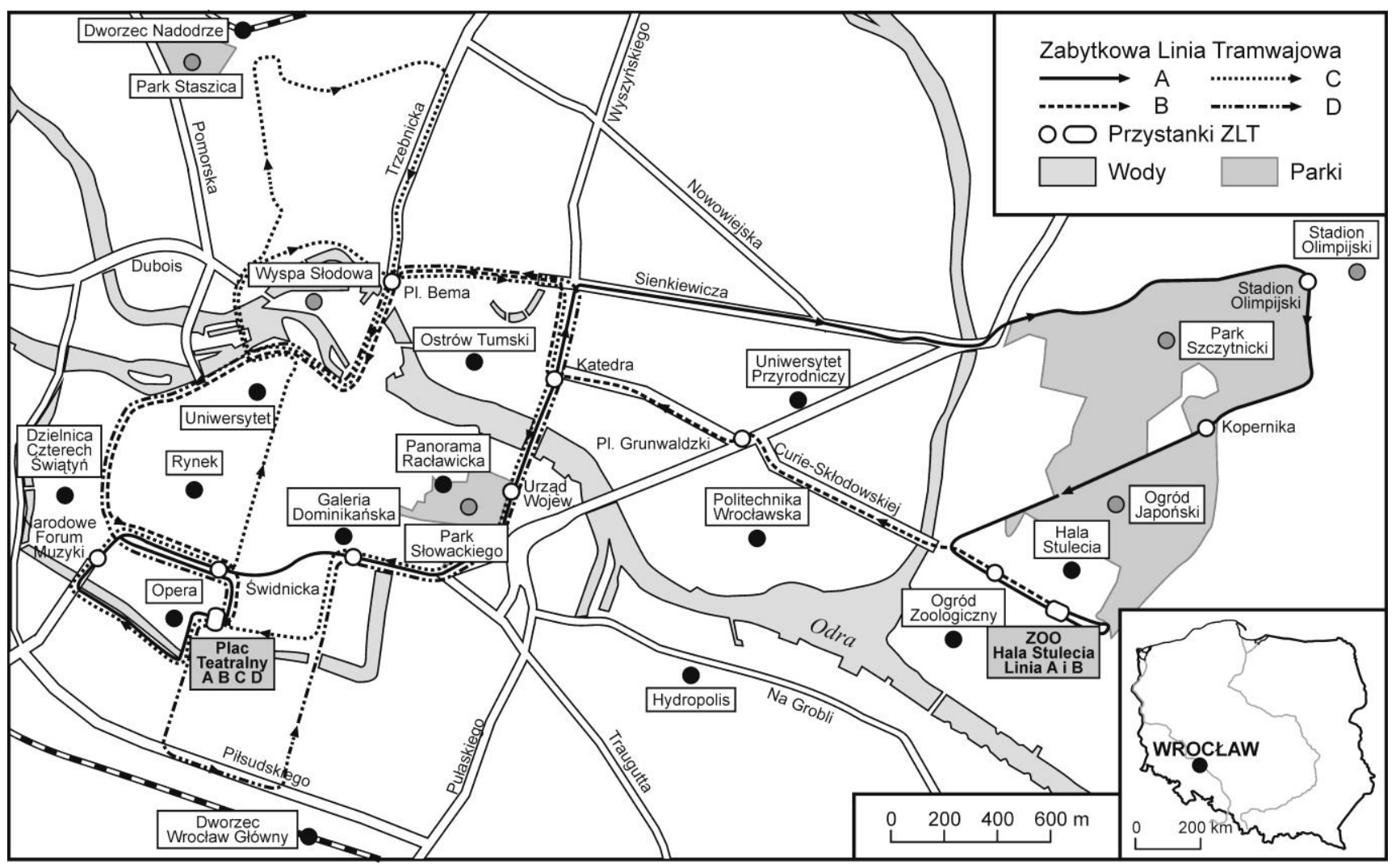

Rys. 2. Schemat czterech tras Zabytkowej Linii Tramwajowej w $2018 \mathrm{r}$ Źródło: opracowanie T. Szymczyszyn, K. Kołodziejczyk; podkład: autorzy OpenStreetMap 
Ostrowa Tumskiego, gmach główny Uniwersytetu Wrocławskiego). W tym przypadku odbywał się tylko jeden kurs o godz. 20.00, tj. przez większość okresu, w którym linia funkcjonowała, o porze zbyt wczesnej, by dostrzec podświetlenie budynków. Trasy A i B były obsługiwane przez KSTM, zaś C i D - przez TMW. Na wszystkich trasach na wybranych kursach podczas przejazdu licencjonowany przewodnik opowiadał o mijanych zabytkach i innych atrakcjach. W przypadku tras A i B przewodnik podczas postoju tramwaju pod Halą Stulecia oprowadzał też chętnych pasażerów po okolicy. Celowo zaproponowano obsługe przewodnicką tylko na wybranych kursach (6 z 11 każdego dnia), by zapewnić możliwość wyboru. Dla niektórych atrakcją jest już bowiem sam przejazd zabytkowym wagonem i oglądanie miasta zza jego okien.

W przypadku linii turystycznych oferta hop on - hop off (wsiadania i wysiadania) jest często i z powodzeniem wykorzystywana $\mathrm{w}$ wielu miastach na Zachodzie, a ostatnio coraz częściej również w Polsce. W związku z wprowadzeniem takiej oferty na Zabytkowej Linii Tramwajowej oraz wyznaczeniem na trasach A i B kilkunastu przystanków KSTM stworzył stanowiska konduktorów, których głównym zadaniem była sprzedaż biletów. Ponadto konduktorzy - rekrutujący się spośród miłośników transportu zbiorowego - w miarę potrzeby opowiadali o historii i szczegółach technicznych tramwaju, który wykonywał dany kurs. Byli oni wyposażeni w historyczne ręczne kasowniki dziurkowe. Turyści mogli więc pokonać całą wybraną przez siebie trasę, co pozwalało im w szybki i wygodny sposób zapoznać się z większością najważniejszych atrakcji turystycznych miasta (trasy A, B, C i D), lub też mogli wysiadać i wsiadać na przystankach zlokalizowanych w pobliżu zabytków celem ich szczegółowego zwiedzenia (trasy A i B). Wadą taryfy był brak biletów jednodniowych, które umożliwiałyby swobodne korzystanie $z$ całej oferty, tj. jeżdżenie wszystkimi trasami. Wynikało to $\mathrm{z}$ potencjalnych trudności $\mathrm{w}$ rozliczeniach między przewoźnikami. Były dostępne tylko bilety jednorazowe (na wszystkie trasy) i powrotne (w przypad$\mathrm{ku}$ tras A i B) w opcjach pełnopłatnej, ulgowej i rodzinnej (dwie osoby dorosłe i maksymalnie troje dzieci). Cena biletów jednorazowych normalnych i ulgowych była narzucona przez Gminę Wrocław, natomiast pozostałych - zaproponowana przez przewoźników. Forma organizacji linii, a przede wszystkim sposób rozliczenia przychodów z biletów uniemożliwiły nawiązanie szerokiej współpracy z zarządcami innych atrakcji turystycznych, nawet będących własnością miejską. Wskazane byłoby bowiem oferowanie wspólnych biletów z zoo lub Halą Stulecia, do których część z zabytkowych tramwajów dowoziła turystów.

Przygotowano polsko-angielskie ulotki reklamujące Zabytkową Linię Tramwajową z mapą tras, rozkładem jazdy i cennikiem, dostępne we wszystkich punktach informacji turystycznej w mieście, oraz ilustrowane ulotki z zarysem historii komunikacji tramwajowej we Wrocławiu, rozdawane bezpłatnie $\mathrm{w}$ tramwajach jako forma pamiątki. Ponieważ zadanie było współfinansowane ze środków publicznych, Gmina Wrocław nie pozwoliła na sprzedaż pocztówek przedstawiających zabytkowe wagony lub innych pamiątek, co czyniłoby ofertę bardziej atrakcyjną. Promocja linii poza ulotkami odbywała się poprzez strony internetowe Gminy Wrocław i obu przewoźników, artykuły zamieszczone w lokalnej prasie i na stronach internetowych (m.in. Krzeszowski, 2018; Ostatnie..., 2018; Wrocławska..., 2018; Zabytkowa..., 2018) oraz za pośrednictwem portali społecznościowych, na których publikowano informacje m.in. o kursujących danego dnia pojazdach czy zmianach tras przejazdu w związku z remontami torowisk. Cała akcja promocyjna była prowadzona wspólnie przez obu przewoźników - reklamowano jedną, łączną ofertę. Linię popularyzowały też niektóre grupy przewodnickie.

Trzeba jednocześnie podkreślić, że wykorzystanie zabytkowych tramwajów we Wrocławiu nie ogranicza się do sezonowej, regularnej linii tramwajowej. Wszystkie sprawne wagony można wynająć na komercyjne przejazdy, np. przewóz turystów z przewodnikiem (co jest szczególnie popularne $\mathrm{w}$ przypadku grup niemieckich), grup szkolnych, gości weselnych, w ramach imprez organizowanych przez firmy (np. wieczory integracyjne). Tramwaje są wykorzystywane też w sesjach fotograficznych. Kursują również podczas różnych wydarzeń odbywających się $\mathrm{w}$ mieście, choć w tym przypadku większa jest aktywność KSTM niż TMW. Najważniejsze z nich to Noc Muzeów - wówczas zabytkowe tramwaje i autobusy umożliwiają przejazd pomiędzy udostępnionymi placówkami i jednocześnie same stanowią atrakcję (na największą skalę takie przedsięwzięcie realizowane jest w Warszawie, ale od trzech lat specjalne linie muzealne, obsługiwane zabytkowym taborem uruchamiane są także we Wrocławiu). Spośród innych wydarzeń, w których uczestniczą historyczne pojazdy, można wymienić Święto Wrocławia i Europejski Tydzień Zrównoważonego Transportu, ale także różne imprezy organizowane przez instytucje kulturalne (np. Muzeum Narodowe czy Instytut Pamięci Narodowej). Dawna zajezdnia tramwajowa Popowice, w której stacjonuje zabytkowy tabor komunikacji miejskiej, nie jest regularnie dostępna dla zwiedzających, co wynika z jej nieprzystosowania do pełnienia takiej funkcji oraz braku funduszy na remont obiektu i utrzymanie regularnej instytucji. Obiekt jest jednak okazjonalnie udostępniany, np. podczas organizowanego już od kilku lat na początku września Dnia Otwartego Zajezdni Popowice, który każdorazowo gromadzi kilka tysięcy osób. 


\section{SPRZEDAŻ BILETÓW ZABYTKOWEJ LINII TRAMWAJOWEJ W 2018 R.}

Podstawową informacją na temat wykorzystania przez turystów oferty Zabytkowej Linii Tramwajowej są dane o sprzedaży biletów, przygotowane przez KSTM w podziale na poszczególne dni i kursy, przez TMW zaś tylko sumarycznie dla trzech okresów rozliczeniowych ${ }^{2}$, co niestety utrudnia bardziej szczegółowe analizy całej oferty. Największy udział w sprzedanych biletach, których turyści kupili łącznie nieco ponad 2000 (tab. 1), miały bilety jednorazowe ulgowe i normalne (odpowiednio $44,42 \%$ i $26,03 \%$ ). Wynika z faktu, że na trasach C i D dostępne były wyłącznie bilety jednorazowe, choć ten typ biletów był też dość popularny na trasach A i B (odpowiednio trzecie i pierwsze miejsce). Zwraca uwage - trudna do wyjaśnienia - zupełnie odwrotna proporcja pomiędzy liczbą sprzedanych biletów jednorazowych normalnych i ulgowych u obu przewoźników. W przypadku KSTM sprzedaż biletów normalnych była prawie dwa razy większa niż ulgowych, zaś w przypadku TMW - ulgowych prawie cztery razy większa niż normalnych. Można próbować to wytłumaczyć nieznajomością obowiązującej taryfy u pracowników TMW, $\mathrm{w}$ poprzednim roku bowiem na okrężnych trasach po centrum miasta rzeczywiście obowiązywały bilety za 4 zł, a nie za 8 zł jak w 2018 r. Inną przyczyną mogło być mniejsze zachęcanie do zakupu biletów rodzinnych, których udział w przypadku TMW wynosi 6,66\%, zaś w przypadku KSTM - 14,85\% (łącznie jednorazowe i powrotne; wyłącznie jednorazowe - 6,90\%). W przypad$\mathrm{ku}$ tras A i B najpopularniejsze były bilety jednorazowe normalne $(32,12 \%)$, powrotne normalne $(21,38 \%)$, jednorazowe ulgowe $(18,11 \%)$ i powrotne ulgowe $(13,54 \%)$. Trzeba jednak pamiętać, że z biletów rodzinnych korzystało od trzech do pięciu osób, zatem ich udział w liczbie przewiezionych pasażerów był znacznie wyższy.

W odniesieniu do przychodów ze sprzedaży biletów sytuacja wygląda nieco inaczej z racji zróżnicowanych cen (tab. 1). Łącznie dla wszystkich tras największy zysk przyniosły bilety jednorazowe normalne i ulgowe - odpowiednio $26,86 \%$ i $22,92 \%$. Na kolejnych miejscach znalazły się bilety normalne powrotne $(17,58 \%)$ oraz - ze zbliżonymi wartościami - rodzinne jednorazowe i powrotne $(14,02 \%$ i $13,05 \%)$. W przypadku tras obsługiwanych przez KSTM zwracają uwagę prawie identyczne przychody ze sprzedaży biletów normalnych jednorazowych i powrotnych $(26,54 \%$ i $26,50 \%)$ oraz dość wysokie znaczenie obu rodzajów biletów rodzinnych $(19,67 \%$ dla powrotnych i $11,42 \%$ dla jednorazowych). Trzeba więc uznać, że wprowadzenie biletów

Tab. 1. Sprzedaż biletów Zabytkowej Linii Tramwajowej w 2018 r. w podziale na typy biletów

\begin{tabular}{|c|c|c|c|c|c|c|c|}
\hline \multirow{3}{*}{ Wyszczególnienie } & \multicolumn{3}{|c|}{ Bilety jednorazowe } & \multicolumn{3}{|c|}{ Bilety powrotne } & \multirow{3}{*}{ Łącznie } \\
\hline & normalne & ulgowe & rodzinne & normalne & ulgowe & rodzinne & \\
\hline & $8 \mathrm{zl}$ & $4 \mathrm{zł}$ & $16 \mathrm{zl}$ & $12 \mathrm{zł}$ & $6 \mathrm{zł}$ & $24 \mathrm{zl}$ & \\
\hline $\begin{array}{l}\text { Łączna liczba sprzedanych } \\
\text { biletów na wszystkich } \\
\text { trasach }\end{array}$ & 525 & 896 & 137 & 229 & 145 & 85 & 2017 \\
\hline $\begin{array}{l}\text { Średnia liczba sprzedanych } \\
\text { biletów na wszystkich } \\
\text { trasach w przeliczeniu na } \\
\text { jeden dzień kursowania }\end{array}$ & 20,19 & 34,46 & 5,27 & 8,81 & 5,58 & 3,27 & 77,58 \\
\hline $\begin{array}{l}\text { Liczba sprzedanych biletów } \\
\text { na trasach A i B }\end{array}$ & 344 & 194 & 74 & 229 & 145 & 85 & 1071 \\
\hline $\begin{array}{l}\text { Liczba sprzedanych biletów } \\
\text { na trasach C i D }\end{array}$ & 181 & 702 & 63 & - & - & - & 946 \\
\hline $\begin{array}{l}\text { Łączny przychód ze sprze- } \\
\text { daży biletów na wszystkich } \\
\text { trasach ( } \mathrm{w} \text { zł) }\end{array}$ & 4200,00 & 3584,00 & 2192,00 & 2748,00 & 870,00 & 2040,00 & 15634,00 \\
\hline $\begin{array}{l}\text { Średni przychód ze sprze- } \\
\text { daży biletów na wszystkich } \\
\text { trasach w przeliczeniu na } \\
\text { jeden dzień kursowania } \\
\text { (w zł) }\end{array}$ & 161,54 & 137,85 & 84,31 & 105,69 & 33,46 & 78,46 & 601,31 \\
\hline $\begin{array}{l}\text { Przychód ze sprzedaży } \\
\text { biletów na trasach A i B } \\
\text { (w zł) }\end{array}$ & 2752,00 & 776,00 & 1184,00 & 2748,00 & 870,00 & 2040,00 & 10370,00 \\
\hline $\begin{array}{l}\text { Przychód ze sprzedaży } \\
\text { biletów na trasach C i D } \\
\text { (w zł) }\end{array}$ & 1448,00 & 2808,00 & 1008,00 & - & - & - & 5264,00 \\
\hline
\end{tabular}

Źródło: opracowanie własne. 
powrotnych i rodzinnych spotkało się z zainteresowaniem podróżnych, których duża część odbywała pełną podróż na trasach A i B. Dotyczy to w szczególności rodzin, prawie dwa razy częściej nabywających bilety powrotne niż ważne tylko na jeden przejazd. Trzeba podkreślić, że cały przychód z biletów musiał zostać przeznaczony na realizację zadania, w praktyce głównie na utrzymanie tramwajów.

Opierając się na informacjach na temat liczby sprzedanych biletów, można ocenić stopień wykorzystania oferty, czyli stosunek rzeczywistej liczby przewiezionych pasażerów do ich maksymalnej potencjalnej liczby $^{3}$. Zakłada się, że optymalną formą jest oczywiście podróż na miejscu siedzącym, choć jazda na stojąco jest też dopuszczona. Tramwaje kursujące $\mathrm{z}$ reguły $\mathrm{w}$ soboty miały odpowiednio 32 i 16 miejsc siedzących, zaś w niedzielę - po 32 miejsca. Uwzględniając liczbę kursów każdego dnia, da się łatwo obliczyć, że pojazdy te mogły przewieźć 272 osoby siedzące w każdą sobotę i 352 w każdą niedzielę. Natomiast biorąc pod uwagę liczbę osób uprawnionych do przejazdu po zakupie danego typu biletów (tab. 1), można stwierdzić, że z ofer-

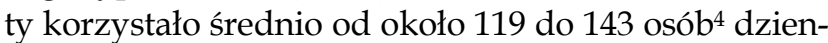
nie. Statystycznie więc zajęta była mniej niż połowa miejsc. W skali całego sezonu kursowania Zabytkowa Linia Tramwajowa potencjalnie mogła przewieźć na miejscach siedzących 8112 pasażerów, a w rzeczywistości było ich od 3090 do 3704. Stopień wykorzystania oferty wynosił zatem od $38,09 \%$ do $45,66 \%$. Warto te zależności prześledzić też dla obu przewoźników z osobna. W przypadku KSTM - przy założeniu, że przez cały sezon kursował wagon Konstal 102Na z 32 miejscami siedzącymi (kilka razy pojawił się jednak mniejszy wagon - Konstal 4N1 z 16 miejscami) - całkowita potencjalna liczba pasażerów to 4992. W rzeczywistości zaś przewieziono od 2018 do 2506 osób, co daje stopień wykorzystania od 40,42\% do 50,20\%. Z kolei TMW na 3120 potencjalnych pasażerów miało ich w rzeczywistości od 1072 do 1198, stąd nieco niższy stopień wykorzystania - od 34,36\% do $38,40 \%$.

Szczegółowe dane dotyczące sprzedaży biletów na poszczególnych kursach są dostępne tylko dla tras A i B (tab. 2). Widać wyraźnie, że najwięcej osób rozpoczynało podróż podczas przejazdów tramwaju z centrum miasta do Hali Stulecia, czyli kursów zaczynających na przystanku Opera o godz. 12.00, 14.00 i 16.00. Na te trzy kursy w całym okresie funkcjonowania wyżej wymienionych tras sprzedano łącznie 816 biletów, co daje 76,19\% ogółu biletów rozdysponowanych przez KSTM. Największą popularnością cieszyły się kursy o godz. 14.00, a najmniejszą - o godz. 17.15 (ostatni powrót z Hali Stulecia do centrum). Biorąc pod uwage pary kursów (tam i z powrotem), najwięcej biletów sprzedawano na drugą z wymienionych par kursów (o godz. 14.00), najmniej zaś - na trzecią (o godz. 16.00), co jest o tyle zaskakujące, że w przypadku tras A i B były to jedyne kursy oferowane z usługą przewodnicką. Zważywszy na relatywnie dużą popularność kursów o godz. 12.00, można się zastanawiać, czy Zabytkowa Linia Tramwajowa nie powinna rozpoczynać kursowania wcześniej, zapewniając dojazd do Hali Stulecia, zoo i parku Szczytnickiego (czyli tradycyjnych miejsc wypoczynku wrocławian) już od rana, dzięki czemu pasażerowie mieliby możliwość spędzenia tam całego dnia.

Udział poszczególnych typów biletów sprzedawanych na konkretnych kursach jest dość zróżnicowany (tab. 3). W przypadku kursów zaczynających się przy operze, podczas pierwszego kursu (12.00) sprzedawano więcej biletów jednorazowych, w szczególności pełnopłatnych, zaś w czasie drugiego (14.00) - biletów powrotnych, przy czym wyraźnie większy jest udział opcji ulgowej. Dość wysokie są też udziały biletów powrotnych na ostatnim kursie z opery (16.00). Taki wynik można utożsamiać $\mathrm{z}$ dostępną właśnie wtedy ofertą przewodnicką, ale - z drugiej strony - jest on o tyle zaskakujący, że bilety powrotne były ważne przez cały dzień (nie było konieczności wracania od razu tym samym tramwajem), dlatego jeśli ktoś planował dłuższy pobyt na terenach rekreacyjnych we wschodniej części miasta, bardziej opłacalne byłoby skorzystanie z kursu już w południe. Zwraca uwage nieco wyższy udział biletów rodzinnych powrotnych podczas kursów z przewodnikiem (16.00). W przypadku przejazdów w odwrotnym kierunku (z Hali Stulecia do centrum) kursy

Tab. 2. Liczba sprzedanych biletów na trasach A i B Zabytkowej Linii Tramwajowej w 2018 r. w podziale na rodzaje biletów i poszczególne kursy

\begin{tabular}{|c|c|c|c|c|c|c|c|}
\hline \multirow{3}{*}{$\begin{array}{c}\text { Kurs } \\
\text { o godz. }\end{array}$} & \multicolumn{3}{|c|}{ Bilety jednorazowe } & \multicolumn{3}{|c|}{ Bilety powrotne } & \multirow{3}{*}{ Łącznie } \\
\hline & normalne & ulgowe & rodzinne & normalne & ulgowe & rodzinne & \\
\hline & $8 \mathrm{zl}$ & $4 \mathrm{zl}$ & $16 \mathrm{zl}$ & $12 \mathrm{zl}$ & $6 \mathrm{zl}$ & $24 \mathrm{zl}$ & \\
\hline 12.00 & 97 & 34 & 18 & 68 & 35 & 25 & 277 \\
\hline 13.15 & 21 & 23 & 10 & 15 & 8 & 5 & 82 \\
\hline 14.00 & 71 & 44 & 14 & 80 & 72 & 20 & 301 \\
\hline 15.15 & 46 & 35 & 11 & 2 & 1 & 8 & 103 \\
\hline 16.00 & 66 & 38 & 14 & 64 & 29 & 27 & 238 \\
\hline 17.15 & 43 & 20 & 7 & 0 & 0 & 0 & 70 \\
\hline Suma & 344 & 194 & 74 & 229 & 145 & 85 & 1071 \\
\hline
\end{tabular}

Źródło: opracowanie własne. 
Tab. 3. Udział (w \%) poszczególnych typów sprzedanych biletów na trasach A i B Zabytkowej Linii Tramwajowej w 2018 r. $\mathrm{w}$ podziale na kolejne kursy

\begin{tabular}{|l|c|c|c|c|c|c|c|}
\hline \multirow{2}{*}{$\begin{array}{c}\text { Kurs } \\
\text { o godz. }\end{array}$} & \multicolumn{3}{|c|}{ Bilety jednorazowe } & \multicolumn{3}{c|}{ Bilety powrotne } & \multirow{2}{*}{ Łącznie } \\
\cline { 2 - 8 } & normalne & ulgowe & rodzinne & normalne & ulgowe & rodzinne \\
\hline 12.00 & $8 \mathrm{zl}$ & $4 \mathrm{zl}$ & $16 \mathrm{zl}$ & $12 \mathrm{zl}$ & $6 \mathrm{zl}$ & $24 \mathrm{zl}$ & \\
\hline 13.15 & 35,02 & 12,27 & 6,50 & 24,55 & 12,64 & 9,03 & 100,00 \\
\hline 14.00 & 25,61 & 28,05 & 12,20 & 18,29 & 9,76 & 6,10 & 100,00 \\
\hline 15.15 & 23,59 & 14,62 & 4,65 & 26,58 & 23,92 & 6,64 & 100,00 \\
\hline 16.00 & 44,66 & 33,98 & 10,68 & 1,94 & 0,97 & 7,77 & 100,00 \\
\hline 17.15 & 27,73 & 15,97 & 5,88 & 26,89 & 12,18 & 11,34 & 100,00 \\
\hline
\end{tabular}

Źródło: opracowanie własne.

o godz. 13.15 odznaczały się większym udziałem biletów powrotnych, których z kolei relatywnie mało sprzedano podczas kursów o godz. 15.15 (podczas kursów o godz. 17.15 nie sprzedawano biletów powrotnych, ponieważ tramwaj nie wracał już pod Halę Stulecia). Przedstawione dane trzeba jednak traktować z pewną rezerwą, ponieważ przy dość niewielkiej liczebności sprzedanych biletów każdego rodzaju na wyniki mogły wpływać grupy zorganizowane, które także miały możliwość korzystania z oferty. Przykładowo w przypadku pojawienia się kilku licznych grup dziecięcych udział tego typu biletów ulegał zawyżeniu, czym można próbować wyjaśnić wyraźnie wyższy odsetek ulgowych biletów powrotnych podczas kursów o godz. 14.00.

Problemem pod względem promocji Zabytkowej Linii Tramwajowej są różne daty rozpoczęcia i zakończenia jej kursowania w poszczególnych latach. Początkowo (w latach 2009-2011) linia kursowała przez cały rok, następnie zwykle od długiego weekendu majowego do jesieni, ostatnio zaś - od czerwca do września. Jest to wynik problemów z finansowaniem przedsięwzięcia. Zmienne daty i coraz krótszy okres funkcjonowania linii powodują, że wrocławianie nie są do tej oferty przyzwyczajeni, a oni także stanowią pewien (w niektórych okresach znaczący) odsetek pasażerów.

Każdego roku trzeba więc w zasadzie promować linię od nowa, co przekłada się na relatywnie niskie - ale sukcesywnie rosnące - przychody z biletów podczas pierwszych weekendów kursowania (rys. 3). Ponieważ na trasach A i B w tym roku pojawiły się wagony dotąd niewykorzystywane na tej linii (w szczególności Konstal $102 \mathrm{Na}$, który zaledwie dwa miesiące wcześniej miał premierę po remoncie), podczas pierwszego weekendu zadziałał ,efekt nowości” i przychody były dość duże, ale już podczas kolejnego okazały się najniższe w całym sezonie (pogoda wówczas była dobra, więc trudno $\mathrm{w}$ niej upatrywać przyczyny niskiej frekwencji). Przychody w lipcu i sierpniu na wspomnianych trasach utrzymywały się na dość wysokim, stabilnym poziomie (rys. 3), osiągając z reguły ponad $400 \mathrm{zł}$ dziennie (średnio 466,47 zł). Miało to miejsce pomimo uruchomienia od 30 czerwca 2018 r. przez MPK Wroc-

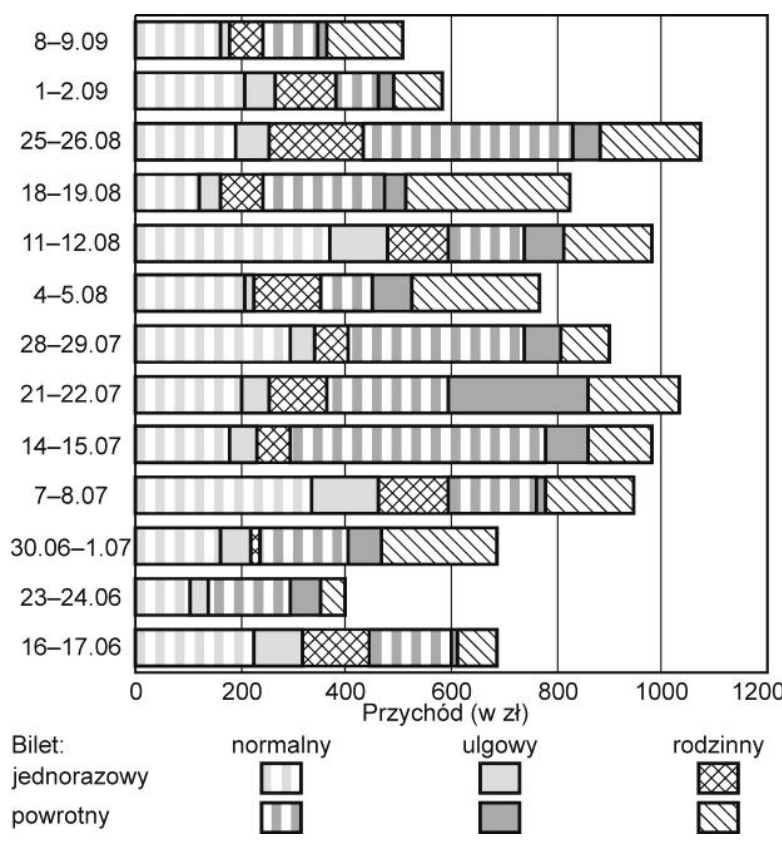

Rys. 3. Przychody (w zł) ze sprzedaży biletów na trasach A i B podczas poszczególnych weekendów kursowania Zabytkowej Linii Tramwajowej w 2018 r. Źródło: opracowanie własne

ław Sp. z o.o. w pewnym sensie konkurencyjnej linii, obsługiwanej jednym tramwajem $\mathrm{z}$ lat $50 . \mathrm{XX} \mathrm{w}$. Wraz z początkiem września odnotowano spadek przychodów, co może świadczyć o typowo sezonowym (wakacyjnym) charakterze zapotrzebowania na przejazdy zabytkowymi tramwajami $w$ ramach regularnej linii. $\mathrm{Z}$ drugiej strony $\mathrm{w}$ przypadku dłuższego $\mathrm{w}$ skali roku okresu funkcjonowania oferty można liczyć na zapisanie się jej w świadomości tak wrocławian, jak i części turystów, a w konsekwencji na wyższą frekwencję i przychody (przy czym oczywiście będą one różne w okresie wakacyjnym i w roku szkolnym). Dowodzi tego porównanie sprzedaży biletów podczas pierwszego i ostatniego weekendu wakacji, a jednocześnie w czasie drugiego i przedostatniego weekendu kursowania linii (por. załączniki). Wyniki są korzystniejsze w drugim przypadku, kiedy linia była obecna $\mathrm{w}$ przestrzeni 
miasta już od dłuższego czasu (pogoda podczas obu weekendów była porównywalna - przeważnie słoneczna i ciepła). Biorąc pod uwage sprzedaż poszczególnych typów biletów w konkretnych dniach (rys. 3), zwraca uwagę wyższy udział biletów jednorazowych normalnych 8 i 29 lipca oraz 11 sierpnia, jednorazowych rodzinnych 25 sierpnia, powrotnych normalnych 14, 15 i 29 lipca oraz 25 sierpnia, powrotnych ulgowych zaś 21 lipca (wynik przewozu zorganizowanej grupy dziecięcej).

\section{OPŁACALNOŚĆ FUNKCJONOWANIA LINII I ANALIZA SWOT}

Koszty funkcjonowania Zabytkowej Linii Tramwajowej różnią się nieznacznie zależnie od przewoźnika (tab. 4), co wynika z uwarunkowań technicznych (np. różna moc silników tramwajów sprawia, że koszty poboru energii trakcyjnej są zróżnicowane) i administracyjnych (np. część prac wykonywana na zasadzie wolontariatu przez członków stowarzyszenia). Biorąc pod uwagę tylko bezpośrednie koszty kursowania tramwajów (pobór energii trakcyjnej, gotowość pogotowia technicznego, korzystanie z infrastruktury, praca motorniczych), przejazdy wagonów na trasach A i B (KSTM) kosztowały 20 747,07 zł, zaś na trasach C i D (TMW) - 19 724,08 zł. Jeśli uwzględni się przychody z biletów w 2018 r. (tab. 1), można dojść do wniosku, że Zabytkowa Linia Tramwajowa nie ma szans na utrzymanie się bez dotacji ze strony Gminy Wrocław. Tak zresztą funkcjonuje od początku z tym zastrzeżeniem, że dotacja zmieniała się z roku na rok i wynosiła od 40 000,00 do 120 000,00 zł.
Poza wymienionymi kosztami trzeba uwzględnić jeszcze przynajmniej druk biletów, utrzymanie tramwajów i pracę przewodników, którzy stali się już ważnym elementem oferty. W 2018 r. dotacja na funkcjonowanie linii wyniosła 100000,00 zł do równego podziału między obu przewoźników. Pozwoliło to na stworzenie oferty nieco atrakcyjniejszej niż w poprzednim roku (np. większa liczba kursów, w tym z obsługą przewodnicką, ulotki dotyczące historii komunikacji tramwajowej we Wrocławiu). Trzeba też pamiętać, że linię obsługuje tabor zabytkowy, który należy w szczególny sposób utrzymywać, a naprawy w przypadku awarii mogą wyjątkowo dużo kosztować i jednocześnie muszą być przeprowadzone możliwie szybko, by zapewnić ciągłość funkcjonowania linii. Stowarzyszenia nie posiadają rozbudowanego zaplecza technicznego, które pozwalałoby na wykonywanie skomplikowanych napraw, dlatego część $\mathrm{z}$ nich jest zlecana firmom mającym doświadczenie $\mathrm{w}$ pracach przy zabytkach techniki (wszystkie wagony wpisane są bowiem do rejestru lub ewidencji zabytków).

Opierając się na przedstawionych powyżej uwarunkowaniach funkcjonowania Zabytkowej Linii Tramwajowej oraz biorąc pod uwagę inne elementy oferty turystycznej Wrocławia, opracowano analizę SWOT (tab. 5). Zaprezentowana $\mathrm{w}$ niniejszym artykule atrakcja turystyczna na pewno wyróżnia się swoją oryginalnością, w szczególności poprzez wykorzystanie do zwiedzania zabytkowych pojazdów, czyli elementu dziedzictwa kulturowego miasta. Wysoka cena biletów i ograniczony zakres dodatkowych atrakcji powoduje jednak, że konkurencyjność między nią a innymi formami poznawania Wrocławia (np. przejazdy melexami) nie jest zbyt duża.

Tab. 4. Koszty (w zł) funkcjonowania Zabytkowej Linii Tramwajowej w 2018 r.

\begin{tabular}{|l|c|c|}
\hline \multicolumn{1}{|c|}{ Wyszczególnienie } & $\begin{array}{c}\text { Klub Sympatyków Transportu } \\
\text { Miejskiego }\end{array}$ & $\begin{array}{c}\text { Towarzystwo Miłośników } \\
\text { Wrocławia }\end{array}$ \\
\hline Pobór energii trakcyjnej przez tramwaje & 7662,85 & 8097,87 \\
\hline Gotowoś pogotowia technicznego & 6251,59 & 5498,10 \\
\hline $\begin{array}{l}\text { Korzystanie z infrastruktury Gminy Wrocław (torowiska } \\
\text { i sieć trakcyjna) }\end{array}$ & 1762,63 & 1448,11 \\
\hline Praca motorniczych & 5070,00 & 4680,00 \\
\hline Praca konduktorów & $\begin{array}{c}4225,00 \\
\text { (wolontariat) }\end{array}$ & 5441,00 \\
\hline Praca przewodników & 3750,00 & 8032,76 \\
\hline $\begin{array}{l}\text { Kontrola stanu technicznego i bieżące utrzymanie } \\
\text { tramwajów }\end{array}$ & $\begin{array}{c}1625,00 \\
\text { (wolontariat) }\end{array}$ & 10692,93 \\
\hline $\begin{array}{l}\text { Naprawy i utrzymanie tramwajów oraz usuwanie skutków } \\
\text { zdarzeń drogowych, w tym wykolejeń }\end{array}$ & 33244,64 & 522,20 \\
\hline Druk biletów, ulotek, rozkładów jazdy & 2216,95 & 838,48 \\
\hline Ubezpieczenie & 1425,00 & 9547,44 \\
\hline Koszty administracyjne & 2550,00 & 54798,89 \\
\hline Razem & 69783,66 & \\
\hline
\end{tabular}

Źródło: opracowanie własne. 
Tab. 5. Analiza SWOT dla Zabytkowej Linii Tramwajowej

\begin{tabular}{|c|c|}
\hline Mocne strony & Słabe strony \\
\hline $\begin{array}{l}\text { - wykorzystanie autentycznych zabytków do przemieszczania się } \\
\text { po mieście } \\
\text { - } \text { wygodny sposób na zobaczenie najważniejszych zabytków } \\
\text { w krótkim czasie } \\
\text { - lokalizacja przystanków przy najważniejszych zabytkach i atra- } \\
\text { kcjach miasta } \\
\text { - } \text { różnorodność pojazdów kursujących na linii (reprezentują okres } \\
\text { od dwudziestolecia międzywojennego do lat } 70 . \mathrm{XX} \text { w.) } \\
\text { - } \text { możliwość przejazdu zarówno z komentarzem przewodnika, } \\
\text { jak i bez niego } \\
\text { - } \text { brak dodatkowej płatności za usługę przewodnicką } \\
\text { - } \text { bezpłatne ulotki dotyczące historii komunikacji tramwajowej } \\
\text { we Wrocławiu } \\
\text { - obsługiwanie linii przez miłośników dziedzictwa transportu } \\
\text { zbiorowego }\end{array}$ & $\begin{array}{l}\text { - dość wysoka cena za przejazd, zwłaszcza dla indywidu- } \\
\text { alnych turystów } \\
\text { - } \text { konieczność dostosowania się turystów do godzin odjaz- } \\
\text { dów z poszczególnych przystanków } \\
\text { - } \text { brak możliwości dojazdu do niektórych atrakcji czy za- } \\
\text { trzymania się przy nich } \\
\text { - brak kursów w godzinach porannych, kiedy wrocławia- } \\
\text { nie udają się do Hali Stulecia i parku Szczytnickiego } \\
\text { - bardzo różna pojemność wagonów kursujących na linii } \\
\text { - brak możliwości zakupu pocztówek lub innych pamiątek } \\
\text { - } \text { usługa przewodnicka tylko w języku polskim }\end{array}$ \\
\hline Szanse & Zagrożenia \\
\hline 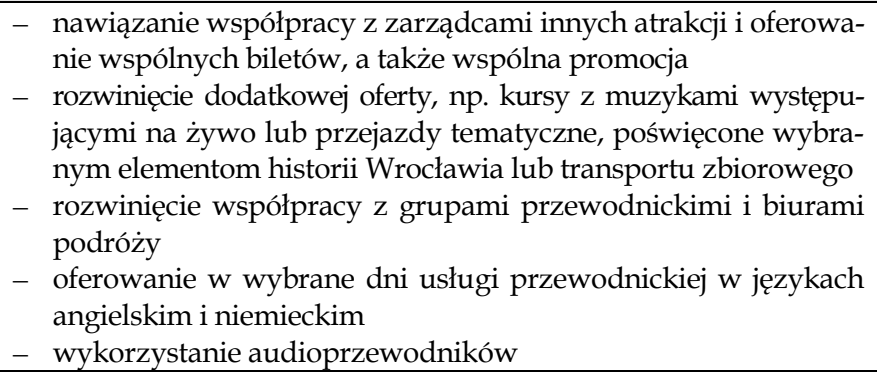 & 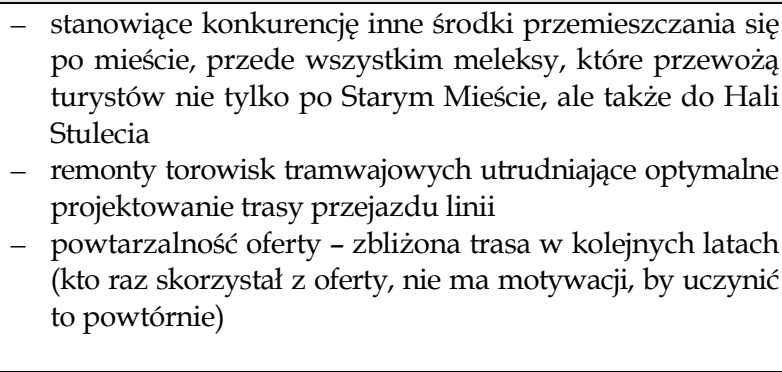 \\
\hline
\end{tabular}

Źródło: opracowanie własne.

\section{WNIOSKI}

Jak zauważyła Meyer (2011, s. 15), „współcześnie środki transportu coraz częściej stają się samodzielnymi atrakcjami turystycznymi, będącymi celem podróży turystycznych" (zob. też Meyer, 2009). Wynika to z faktu, że transport relatywnie szybko poza realizacją funkcji przewozowej stał się jedną z atrakcji związanych z podróżą o charakterze turystycznym (por. Maćkowiak, 2015; Pawlusiński, 2007). Zabytkowa Linia Tramwajowa, która już od 10 lat kursuje po Wrocławiu, może zostać bez wątpienia uznana za atrakcję turystyczną. Zabytkowe wagony po pierwsze przypominają, jak zmieniał się transport w ciągu ostatniego wieku (najstarszy wagon kursujący na linii reprezentuje serię Linke-Hofmann Standard, produkowaną w latach 1925-1929; Jerczyński, 2001), po drugie - umożliwiają sprawne przemieszczanie się pomiędzy atrakcjami miasta oraz stanowią ciekawą formę ich oglądania i poznawania. W 2018 r. oferta została rozbudowana w stosunku do poprzednich lat, co wynikało z wprowadzenia drugiego przewoźnika (Klub Sympatyków Transportu Miejskiego) obok dotychczasowego (Towarzystwo Miłośników Wrocławia). Wprowadzono ważne dla pasażerów zmiany w funkcjonowaniu linii (m.in. dodanie przystanków w ramach oferty hop on - hop off, nowe rodzaje biletów, większa liczba kursów z przewodnikiem, atrakcyjniejsze wizualnie materiały graficzne). Skutkiem tego było również pozyskanie dość szczegółowych danych dotyczących wykorzystania tej oferty. Informacje o sprzedaży biletów pozwoliły ustalić, że największą popularnością cieszy się ona w lipcu i sierpniu, ale średni odsetek zajętych miejsc siedzących to około $40 \%$, czyli potencjał nie jest w pełni wykorzystany. Zaskakujące jest, że z największym zainteresowaniem niekoniecznie spotykały się kursy z obsługą przewodnicką. Nowe rodzaje biletów (rodzinne, powrotne) cieszyły się dość dużą popularnością, ponieważ były korzystniejsze cenowo, co stało się ważne $\mathrm{w}$ obliczu wzrostu cen względem poprzedniego roku (wynikał on z decyzji władz miasta). Jednoznaczne jest też, że przewoźnicy nie byliby w stanie utrzymać linii bez dotacji, bazując tylko na przychodach z biletów (i ewentualnie sprzedaży pamiątek).

Analiza funkcjonowania linii w 2018 r. pozwoliła na wyciągnięcie pewnych wniosków, które mogą pomóc $\mathrm{w}$ poprawieniu oferty. Pomimo mniejszego zainteresowania nią w czerwcu i we wrześniu wydaje się, że linia powinna zaczynać kursować już w długi weekend majowy, a kończyć - na przełomie września i października (choć tramwaje mogą wówczas jeździć z mniejszą częstotliwością). Dzięki temu będzie ona obecna w krajobrazie miasta - ale też w świadomości wrocławian i turystów, co w konsekwencji może przyczynić 
się do podwyższenia średnich przechodów. Można też rozważyć uruchamianie kursów do Hali Stulecia jeszcze przed południem, co powinno ułatwić dojazd osobom chętnym spędzić w tej atrakcyjnej części miasta cały dzień. Należy wprowadzić bilety jednodniowe (lub nawet weekendowe), dzięki czemu będzie możliwe pełne wykorzystanie oferty hop on - hop off, a także bilety łączone, obejmujące linię i wybrane inne miejskie atrakcje turystyczne, w szczególności zoo i Halę Stulecia. Z linią powinny być związane różnego rodzaju pamiątki (np. pocztówki, breloczki, modele zabytkowych tramwajów), co czyniłoby ofertę pełniejszą i miałoby wpływ na wynik finansowy. Warto też rozważyć inne formy czynienia przejazdu atrakcyjniejszym. Opowieść przewodnika to standard stosowany na większości linii turystycznych, choć w przypadku Wrocławia zaskakujące jest to, że kursy z przewodnikiem nie są wybierane częściej niż przejazdy bez tej oferty. Można by rozważyć kursy z muzykami grającymi na żywo na pokładzie tramwaju. Klub Sympatyków Transportu Miejskiego realizuje już takie przejazdy od września 2017 r. we współpracy z jednym z klubów jazzowych. Cieszą się one bardzo dużą popularnością, ale są darmowe, gdyż mają charakter promocyjny, popularyzatorski lub odbywają się w ramach różnych wydarzeń kulturalnych. Pytanie, czy znaleźliby się chętni na tego typu przejażdżki, gdyby były one płatne.

Tramwajowa linia turystyczna obsługiwana zabytkowym taborem przyciąga turystów możliwością bezpośredniego kontaktu $\mathrm{z}$ dziedzictwem, w tym przypadku dziedzictwem techniki, które w ostatnich latach coraz bardziej zyskuje na popularności. Grupa miłośników zabytkowych środków transportu jest jednak stosunkowo mała i w celu przyciągnięcia większej liczby klientów i zapewnienia przedsięwzięciu opłacalności ekonomicznej niezbędne wydaje się połączenie produktu rzeczywistego (Kaczmarek, Stasiak, Włodarczyk, 2010), czyli przejazdu zabytkowym tramwajem, z dodatkowymi atrakcjami. Podstawą jest możliwość poznawania miasta $\mathrm{z}$ okien pojazdu, słuchając komentarzy przewodnika, ale mogą być to też próby łączenia kultury technicznej z kulturą wysoką, np. poprzez występy zespołów muzycznych w wagonie. Wydaje się, że historyczne tramwaje na razie są w stanie samodzielnie generować ruch turystyczny tylko w miastach, w których decydują o ich genius loci, np. Lizbona czy San Francisco. Jak dotąd zabytkowe pojazdy nie spełniają takiej funkcji we Wrocławiu.

\section{PRZYPISY}

${ }^{1}$ Wrocławskie zabytkowe tramwaje $\mathrm{w}$ większości mają swoje nazwy własne.

${ }^{2}$ Okresy rozliczeniowe mają różną długość, dlatego na podstawie tych danych trudno wyciągnąć jakieś wnioski odno- śnie do zmienności $\mathrm{w}$ czasie przychodów TMW z biletów na przejazd.

${ }^{3} \mathrm{~W}$ literaturze dotyczącej transportu zbiorowego $\mathrm{w}$ tym kontekście często stosuje się pojęcie napełnienia (por. m.in. Gill, Gramza, 2016; Starowicz, 2007; Stasiak, Kiciński, 2014).

${ }^{4}$ Przedział wartości wynika z założenia, że z jednego biletu rodzinnego mogło korzystać w czasie podróży jednocześnie od trzech do pięciu osób. W przypadku biletów powrotnych liczba pasażerów implikuje podwojenie liczby sprzedanych biletów, gdyż każda osoba używała ich podczas dwóch kursów.

\section{BIBLIOGRAFIA}

Ashworth, G.J. (1992). Is there an urban tourism? Tourism Recreation Research, 17 (2), 3-8.

Bufe, S. (red.) (1992). Strassenbahnen in Schlesien. Egglham: Bufe-Fachbuch-Verlag.

Cudny, W. (2018). Car tourism. Cham: Springer.

Cudny, W., Horňák, M. (2016). The tourist function in a car factory Audi Forum Ingolstadt example. Bulletin of Geography. Socioeconomic Series, 33, 23-38.

Gill, A., Gramza, G. (2016). Poziom napełnienia stref dla osób stojących w tramwaju jako miernik ocen jakości ich zabudowy i atrakcyjności dla pasażerów. Autobusy: Technika, Eksploatacja, Systemy Transportowe, 12, 612-617.

Goranczewski, B., Puciato, D. (2010). Zastosowanie analizy SWOT $\mathrm{w}$ formułowaniu strategii rozwoju turystyki na obszarach recepcyjnych. Turyzm/Tourism, 20 (2), 45-53.

Jerczyński, M. (2001). Wrocławskie wagony tramwajowe typu standard. Świat Kolei, 6, 44-48.

Kaczmarek, J., Stasiak, A., Włodarczyk, B. (2010). Produkt turystyczny. Pomyst, organizacja, zarzadzanie. Warszawa: PWE.

Kołodziejczyk, K. (2011). Historia, stan i perspektywy wykorzystania w turystyce dziedzictwa wrocławskiej komunikacji tramwajowej. W: K. Widawski (red.), Turystyka kulturowa na Dolnym Ślasku - wybrane aspekty. T. 2 (s. 119-150). Wrocław: Instytut Geografii i Rozwoju Regionalnego Uniwersytetu Wrocławskiego.

Kołodziejczyk, K. (2018). Potencjał polskich miast pod względem zabytkowych tramwajów i ich wykorzystanie w turystyce. Ekonomiczne Problemy Turystyki, 2 (42), 209-224.

Kowalczyk, A. (2005). Nowe formy turystyki miejskiej. Prace i Studia Geograficzne, 35, 155-197.

Kruczek, Z. (2011). Atrakcje turystyczne. Fenomen, typologia, metody badań. Kraków: Proksenia.

Krzeszowski, J. (2018). Startuje zabytkowa linia tramwajowa. Pobrane z: https://www.Wrocław.pl/zabytkowa-linia-tramwajowa (15.06.2018).

Lewandowski, K., Molecki, B. (red.) (2006). Tramwaje we Wrocławiu 1877-2006. Wrocław: Oficyna Wydawnicza Politechniki Wrocławskiej.

Lipińska, I. (2011). Turystyka dziedzictwa kulturowego - wybrane aspekty ochrony prawnej parku kulturowego. Turystyka Kulturowa, 3, 14-27.

Maciejewski, J. (2004). O wrocławskich tramwajach. Wrocław: Oficyna Wydawnicza Oddziału Wrocławskiego PTTK „Sudety".

Maćkowiak, R. (2015). Wykorzystanie transportu w turystyce. W: B. Meyer (red.), Obstuga uczestników turystyki i rekreacji. Wybrane aspekty (s. 157-159). Warszawa: Difin.

Marak, J., Wyrzykowski, J. (2010). Klasyfikacja ruchu turystycznego. W: J. Wyrzykowski, J. Marak (red.), Turystyka w ujeciu interdyscyplinarnym (s. 20-29). Wrocław: Wyższa Szkoła Handlowa. 
Matczak, A. (1989). Problemy badania funkcji turystycznej miast Polski. Funkcja turystyczna. Acta Universitatis Lodziensis. Turyzm, 5, 27-39.

Mehring, A. (2017). Komunikacja miejska w obsłudze obiektów turystycznych i rekreacyjnych. Progress. Journal of Young Researchers, 1, 84-95.

Meyer, B. (2009). Historyczne i współczesne znaczenie transportu w turystyce. Problemy Transportu i Logistyki, 7, 149-159.

Meyer, B. (2011). Modyfikacja funkcji pełnionych przez podstawowe formy obsługi ruchu turystycznego. Ekonomiczne Problemy Turystyki, 16, 9-24.

Meyer, B. (2015). Transport jako atrakcja turystyczna. W: B. Meyer (red.), Obstuga uczestników turystyki i rekreacji. Wybrane aspekty (s. 173-177). Warszawa: Difin.

Mika, M. (2007a). Turystyka miejska. W: W. Kurek (red.), Turystyka (s. 319-328). Warszawa: Wydawnictwo Naukowe PWN.

Mika, M. (2007b). Klasyfikacja ruchu turystycznego. W: W. Kurek (red.), Turystyka (s. 197-198). Warszawa: Wydawnictwo Naukowe PWN.

Mikos von Rohrscheidt, A. (2008). Turystyka kulturowa. Fenomen, Potencjat. Perspektywy. Gniezno: Milenium.

Nowacki, M. (2000). Analiza potencjału atrakcji krajoznawczych na przykładzie Muzeum Narodowego w Szreniawie. W: A. Szwichtenberg, E. Dziegieć (red.), Przemyst turystyczny (s. 147-164). Koszalin: Politechnika Koszalińska.

Ostatnie weekendy kursowania wrocławskiej Zabytkowej Linii Tramwajowej (2018). Pobrane z: https://www.tuWrocław. com/wiadomosci,ostatnie-weekendy-kursowania-Wrocławskiej-zabytkowej-linii-tramwajowej,wia5-3266-43428.html (24.09.2018).

Page, S. (1995). Urban tourism. London-New York: Routledge.

Pawlusiński, R. (2007). Transport w turystyce. W: W. Kurek (red.), Turystyka (s. 164-177). Warszawa: Wydawnictwo Naukowe PWN.

Sala, J. (2012). Miasta jako cel podróży turystycznych w Polsce. W: T. Żabińska (red.), Turystyka na obszarach miejskich: uwarunkowania rozwoju, narzędzia promocji (s. 20-32). Katowice: Wydawnictwo Uniwersytetu Ekonomicznego w Katowicach.
Sielicki, T. (2012a). Przez wroctawskich ulic sto... Historia tramwajów we Wroctawiu. Wrocław: Muzeum Miejskie Wrocławia.

Sielicki, T. (2012b). Przez Sępolno, Zalesie i Krzyki - historia wrocławskich tramwajów. W: M. Derwich (red.), O historii Wrocławia i Ślaska inaczej. Vol. 1 (s. 81-105). Wrocław: Wrocławskie Towarzystwo Miłośników Historii.

Sielicki, T. (2013). Historyczny tabor komunikacyjny we Wroctawiu. Wrocław: Centrum Badań nad Miastem (mps).

Sielicki, T. (2017). Wroctawskie tramwaje konne. Łódź: Wydawnictwo Księży Młyn.

Starowicz, W. (2007). Jakość przewozów w miejskim transporcie zbiorowym. Kraków: Wydawnictwo Politechniki Krakowskiej.

Stasiak, P., Kiciński, M. (2014). Badania i ocena stopnia wykorzystania taboru autobusowego w przedsiębiorstwie ZUK Rokbus Spółka z o.o. Logistyka, 3, 5967-5975.

Turystyka-motoryzacyjna.pl. Pobrane z: www.turystyka-motoryzacyjna.pl (23.09.2019).

Tylińska, R. (2005). Analiza SWOT instrumentem w planowaniu rozwoju. Warszawa: WSIP.

Wojcieszak, J. (1993). 100 lat tramwajów elektrycznych we Wroctawiu. Poznań: Poznański Klub Modelarzy Kolejowych.

Wroctawska Zabytkowa Linia Tramwajowa atrakcja dla turystów i mieszkańców (2018). Pobrane z: https://www.tuWrocław. com/ wiadomosci,Wrocławska-zabytkowa-linia-tramwajowaatrakcja-dla-turystow-i-mieszkancow,wia5-3266-42475.html (24.09.2018).

Zabytkowa Linia Tramwajowa kursuje jeszcze przez trzy weekendy (2018). Pobrane z: http://Wrocław. wyborcza.pl/Wrocław/ 7,35771,23816471,zabytkowa-linia-tramwajowa-kursuje-jeszczeprzez-trzy-weekendy.html (24.09.2018).
Artykuł wpłynął: 29 marca $2019 \mathrm{r}$.

Zaakceptowano do druku:

18 kwietnia $2019 \mathrm{r}$ 


\section{ZAŁACCZNIKI}

Liczba sprzedanych biletów na trasach A i B Zabytkowej Linii Tramwajowej podczas drugiego weekendu funkcjonowania linii (23-24.06.2018 r.) w podziale na rodzaje biletów i poszczególne kursy

\begin{tabular}{|c|c|c|c|c|c|c|c|}
\hline \multirow[t]{3}{*}{ Kurs } & \multicolumn{3}{|c|}{ Bilety jednorazowe } & \multicolumn{3}{|c|}{ Bilety powrotne } & \multirow[t]{3}{*}{ Łącznie } \\
\hline & normalne & ulgowe & rodzinne & normalne & ulgowe & rodzinne & \\
\hline & $8 \mathrm{zl}$ & $4 \mathrm{zl}$ & $16 \mathrm{zł}$ & $12 \mathrm{zl}$ & $6 \mathrm{zl}$ & $24 \mathrm{zł}$ & \\
\hline 12.00 & 4 & 1 & 0 & 5 & 4 & 1 & 15 \\
\hline 13.15 & 0 & 0 & 0 & 1 & 0 & 0 & 1 \\
\hline 14.00 & 6 & 2 & 0 & 2 & 1 & 0 & 11 \\
\hline 15.15 & 1 & 4 & 0 & 0 & 0 & 1 & 6 \\
\hline 16.00 & 1 & 1 & 0 & 5 & 5 & 0 & 12 \\
\hline 17.15 & 1 & 0 & 0 & 0 & 0 & 0 & 1 \\
\hline Suma & 13 & 8 & 0 & 13 & 10 & 2 & 46 \\
\hline
\end{tabular}

Źródło: opracowanie własne.

Liczba sprzedanych biletów na trasach A i B Zabytkowej Linii Tramwajowej podczas przedostatniego weekendu funkcjonowania linii (01-02.09.2018 r.) w podziale na rodzaje biletów i poszczególne kursy

\begin{tabular}{|c|c|c|c|c|c|c|c|}
\hline \multirow[t]{3}{*}{ Kurs } & \multicolumn{3}{|c|}{ Bilety jednorazowe } & \multicolumn{3}{|c|}{ Bilety powrotne } & \multirow[t]{3}{*}{ Łącznie } \\
\hline & normalne & ulgowe & rodzinne & normalne & ulgowe & rodzinne & \\
\hline & $8 \mathrm{zl}$ & $4 \mathrm{zl}$ & $16 \mathrm{zl}$ & $12 \mathrm{zl}$ & $6 \mathrm{zl}$ & $24 \mathrm{zl}$ & \\
\hline 12.00 & 7 & 1 & 2 & 3 & 4 & 1 & 18 \\
\hline 13.15 & 2 & 3 & 2 & 0 & 0 & 0 & 7 \\
\hline 14.00 & 4 & 4 & 0 & 0 & 0 & 0 & 8 \\
\hline 15.15 & 8 & 6 & 1 & 0 & 0 & 1 & 16 \\
\hline 16.00 & 3 & 1 & 1 & 4 & 0 & 2 & 11 \\
\hline 17.15 & 2 & 0 & 1 & 0 & 0 & 0 & 3 \\
\hline Suma & 26 & 15 & 7 & 7 & 4 & 4 & 63 \\
\hline
\end{tabular}

Źródło: opracowanie własne. 